\title{
Synthesis of 2-substituted-6-hydroxy and 6-methoxy benzothiazoles from 1,4-benzoquinone
}

\author{
Giuseppe Meroni, ${ }^{\text {a }}$ Mehdi Rajabi, ${ }^{\text {a Paolo Ciana, }},{ }^{b}$ Adriana Maggi, \\ and Enzo Santaniello*a
}

${ }^{a}$ Laboratory of Medical Chemistry, Department of Medicine, Surgery and Dentistry, Faculty of Medicine, Polo Universitario S. Paolo, Università degli Studi di Milano via A. di Rudinì, 8, 20142 Milano, Italy

${ }^{b}$ Center of Excellence on Neurodegenerative Diseases, Department of Pharmacological

Sciences, University of Milan, Via Balzaretti 9, 20133 Milan, Italy

E-mail: enzo.santaniello@unimi.it

DOI: http://dx.doi.org/10.3998/ark.5550190.0011.607

\begin{abstract}
A few 2-substituted-6-hydroxy and 6-methoxybenzothiazoles have been prepared from ethyl 6hydroxybenzothiazole-2-carboxylate, obtained by oxidation of ethyl $(R)-2$-amino-3-(2,5dihydroxyphenylsulfanyl)propanoate hydrochloride, in turn prepared from 1,4-benzoquinone.
\end{abstract}

Keywords: 2-substituted-6-hydroxybenzothiazoles, 2-substituted-6-methoxy benzothiazoles, 1,4-benzoquinone, ethyl 6-hydroxybenzothiazole-2-carboxylate, 2-cyano-6methoxybenzothiazole

\section{Introduction}

The luciferase from the North American firefly Photinus pyralis (PpyLuc) catalyzes the conversion of D-luciferin [ $(S)$-2-(6'-hydroxy-2'-benzothiazolyl)- $\Delta^{2}$-thiazoline-4-carboxylic acid] to oxyluciferin in the presence of ATP, $\mathrm{Mg}^{2+}$, and oxygen with production of a yellow-green light characterized by a broad emission spectrum and a peak at $560 \mathrm{~nm}$ (Figure 1). ${ }^{1}$

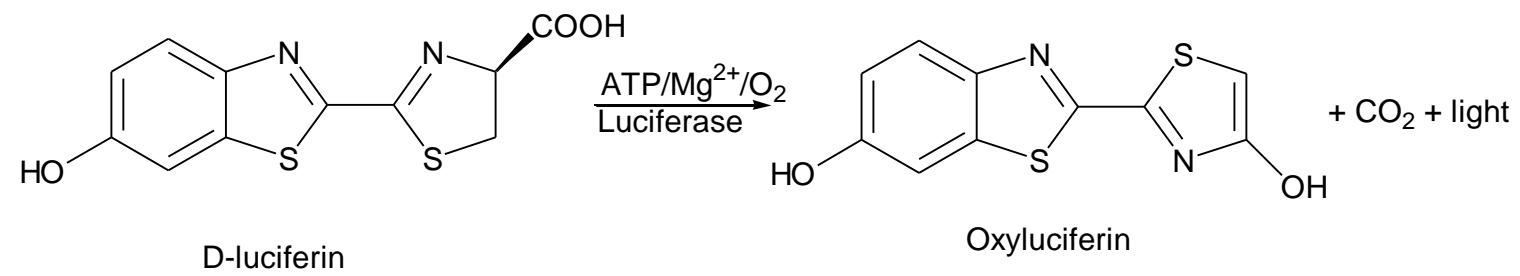

Figure 1. Luciferase-catalyzed production of bioluminescence. 
PpyLuc is a well characterized enzyme that finds a large number of biotechnological applications $^{2}$ and is, at present, the preferred enzyme for in vivo optical imaging of small animals. ${ }^{3}$ We have recently undertaken a project aimed to prepare compounds related to Dluciferin labelled with positron emitting fluorine $\left({ }^{18} \mathrm{~F}\right)$ for the in vivo imaging ${ }^{4}$ of a transgenic mouse that expresses a luciferase reporter gene under the control of activated estrogen receptors. ${ }^{5}$ We have considered the introduction of ${ }^{18} \mathrm{~F}$ into the benzothiazole core of D-luciferin (compounds 1, Figure1) provided that affinity for PpyLuc could be demonstrated. 2,6Disubstituted benzothiazoles (compounds 2a) were required as intermediates for the preparation of compounds $\mathbf{1}$ or as potential probes for imaging, in view of the fact that compounds such as $\mathbf{2 b}$ or $\mathbf{2 c}$ are competitive inhibitors of luciferase. ${ }^{6,7}$
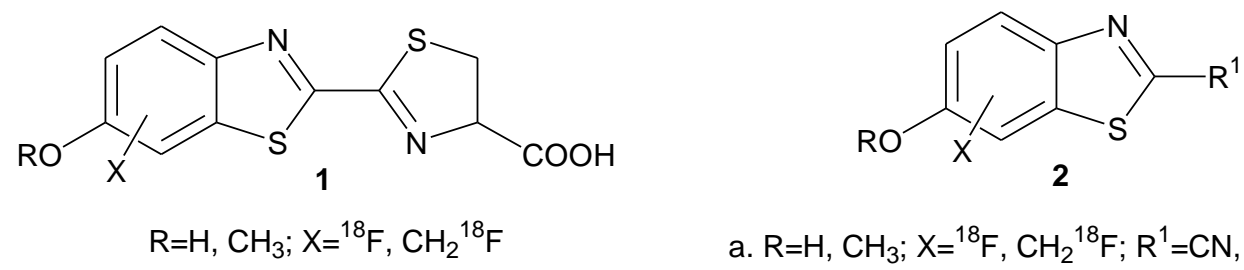
a. $\mathrm{R}=\mathrm{H}, \mathrm{CH}_{3} ; \mathrm{X}={ }^{18} \mathrm{~F}, \mathrm{CH}_{2}{ }^{18} \mathrm{~F} ; \mathrm{R}^{1}=\mathrm{CN}, \mathrm{COOH}, \mathrm{CONH}_{2}$
b. $\mathrm{R}=\mathrm{H}, \mathrm{CH}_{3} ; \mathrm{X}=\mathrm{H} ; \mathrm{R}^{1}=\mathrm{H}, \mathrm{CN}$ c. $\mathrm{R}$ and $\mathrm{R}^{1}$ various; $\mathrm{X}=\mathrm{H}$
d. $\mathrm{R}=\mathrm{H}, \mathrm{CH}_{3} ; \mathrm{X}=\mathrm{H} ; \mathrm{R}^{1}=\mathrm{CO}-\mathrm{NH}-\left(\mathrm{CH}_{2}\right)_{n}{ }^{18} \mathrm{~F}$

Figure 2. Structure of compounds $\mathbf{1}$ and $\mathbf{2 a - d .}$

Within the above project, we have prepared a few compounds structurally related to compounds 2a $(\mathrm{X}=\mathrm{H})$ and evaluated their in vitro affinity for PpyLuc. ${ }^{8}$ 2-Substituted-6-hydroxy and 6-methoxybenzothiazoles such as compounds 4a-d (Scheme 1) were prepared from 2-cyano6-methoxybenzothiazole 3 that is commercially available.<smiles>COc1ccc2nc(C#N)sc2c1</smiles>

3<smiles>N#Cc1nc2ccc(O)cc2s1</smiles>

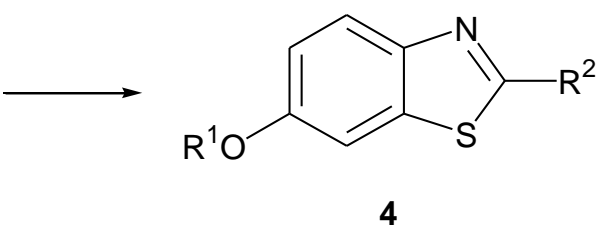

a. $\mathrm{R}^{1}=\mathrm{CH}_{3}, \mathrm{R}^{2}=\mathrm{CONH}_{2}$

c. $\mathrm{R}^{1}=\mathrm{H}, \mathrm{R}^{2}=\mathrm{CONH}_{2}$

d. $\mathrm{R}^{1}=\mathrm{H}, \mathrm{R}^{2}=\mathrm{CN}$

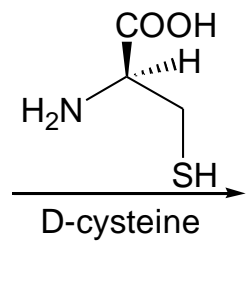<smiles>O=C(O)C1CSC(c2nc3ccc(O)cc3s2)=N1</smiles>

D-luciferin

Scheme 1. Preparation of compounds 4a-d and synthesis of D-luciferin from 2-cyano-6methoxybenzothiazole 3 . 
It should be mentioned that the nitrile $\mathbf{3}$ is an important intermediate for the synthesis of Dluciferin ${ }^{9,10}$ and that the synthesis of this compound has been the target of several publications. ${ }^{10-}$ ${ }^{16}$ We report here the synthesis of a few 2-substituted-6-hydroxy and 6-methoxybenzothiazoles from ethyl 6-hydroxybenzothiazole-2-carboxylate, in turn obtained from 1,4-benzoquinone.

\section{Results and discussion}

The reaction of quinones and cysteine has been extensively studied ${ }^{17-19}$ and from 1,4benzoquinone 5 ethyl $(R)$-2-amino-3-(2,5-dihydroxyphenylsulfanyl)propanoate hydrochloride 6 has been prepared and characterized. ${ }^{20}$ The oxidation of the ester $\mathbf{6}$ has been studied by a few authors ${ }^{20,21}$ and the synthetic procedure most reliable from a preparative point of view is that recently described by Löwik et al. ${ }^{21}$ When the oxidation was carried out with potassium ferricyanide $\mathrm{K}_{3} \mathrm{Fe}(\mathrm{CN})_{6}$ in the presence of $\mathrm{NaOH}$ and methanol or ethanol, mixtures of the thiazines $\mathbf{7 a}$ or $\mathbf{7 b}$ and the ethyl ester $\mathbf{8}$ were obtained (Scheme 2). The thiazines $\mathbf{7 a}$ or $\mathbf{7 b}$ could be isolated by flash chromatography and converted into the benzothiazole ester $\mathbf{8}$ by treatment with $1 \mathrm{M} \mathrm{HCl}$ in methanol or ethanol. The ester $\mathbf{8}$ could also be obtained by acidic treatment of the crude mixtures $\mathbf{7 a} / \mathbf{8}$ or $\mathbf{7 b} / \mathbf{8}$. We have prepared our 2 -substituted-6-hydroxy and 6methoxybenzothiazoles from ethyl $(R)$-2-amino-3-(2,5-dihydroxyphenylsulfanyl) propanoate hydrochloride 6 basically relying upon the original experimental protocol. ${ }^{20}$ Specifically, we have carried out the reaction of 1,4-benzoquinone 5 with L-cysteine ethyl ester hydrochloride in methanol at room temperature, excluding water from the reaction. The ethyl ester $\mathbf{6}$ obtained after the work-up (95\%) could be stored as a solid product ${ }^{23}$ and later oxidized with $\mathrm{K}_{3} \mathrm{Fe}(\mathrm{CN})_{6}$ in aqueous $\mathrm{NaOH}$ in the presence of an alcohol, as described by Löwik et al. ${ }^{21}$ We have selected isopropanol ${ }^{23}$ and carried out the reaction at room temperature. Purification of the crude mixture of products by silica gel column chromatography afforded the ester $\mathbf{8}$ essentially pure (68\%). Furthermore, in order to avoid the high molar ratio $(6: 1)$ of $\mathrm{K}_{3} \mathrm{Fe}(\mathrm{CN})_{6}$ reported in the original procedure ${ }^{21}$ we have attempted a few alternative oxidations. ${ }^{24}$ Finally, we have found that the reaction of cupric salts with the ester 6 (molar ratio, 3:1) in isopropanol/water can constitute an alternative to the procedure involving $\mathrm{K}_{3} \mathrm{Fe}(\mathrm{CN})_{6}{ }^{25}$

The synthesis of 2-substituted 6-hydroxy and 6-methoxybenzothiazoles from the ester $\mathbf{8}$ is illustrated in Scheme 3. Thus, protection of the ester 8 as the corresponding 6-O-methyl ether 9 ( $92 \%$ yield) and following quantitative reaction with concentrated aqueous ammonia ${ }^{26}$ afforded the amide 4a. This amide could also be prepared by methylation of 2-carboxyamide-6hydroxybenzothiazole $\mathbf{4 c}$, in turn obtained from the ester $\mathbf{8}$ by treatment with concentrated aqueous ammonia (98\%). However, methylation of the amide $\mathbf{4 c}$ was less straightforward, due to the formation of side products, presumably occurring from the methylation of the 2carboxyamide function. Finally, the transformation of the amide $\mathbf{4 a}$ into the nitrile $\mathbf{3}$ was carried out using $\mathrm{POCl}_{3}$ as dehydrating agent (72\% yield). ${ }^{27}$ 


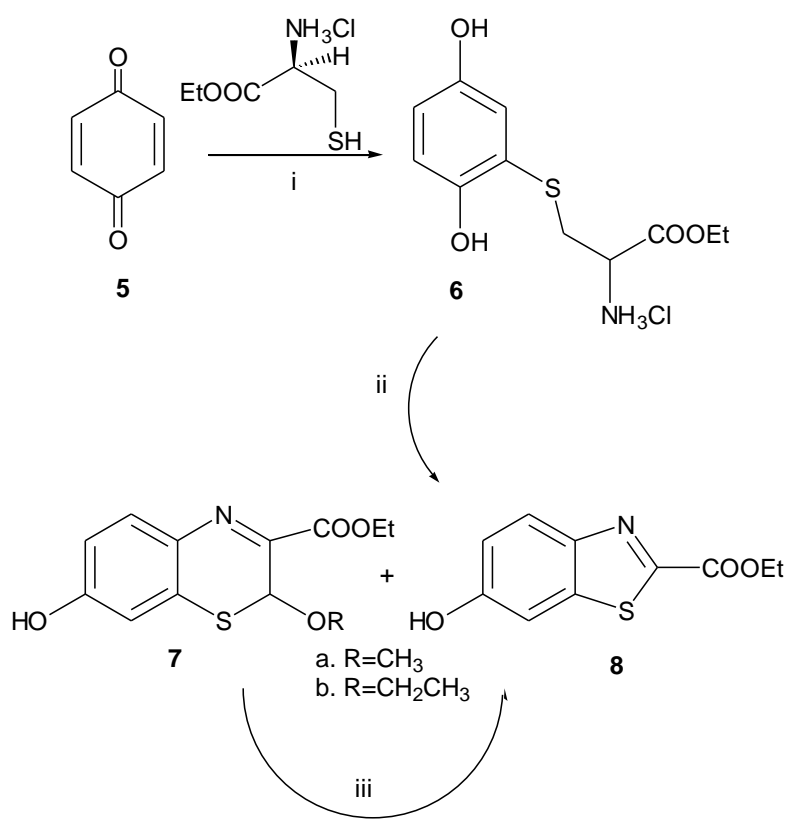

Scheme 2. Preparation and oxidation of the ester 8. Reagents and conditions: (i) $\mathrm{MeOH}$, room temperature, $1 \mathrm{~h}, 95 \%$; (ii) $\mathrm{K}_{3} \mathrm{Fe}(\mathrm{CN})_{6}, \mathrm{NaOH}$, aq. $\mathrm{MeOH}$ or EtOH, room temperature, $1 \mathrm{~h}, 58 \%$; (iii) $1 \mathrm{~N} \mathrm{HCl}, \mathrm{EtOH}$, room temperature, $24 \mathrm{~h}, 86 \%$.

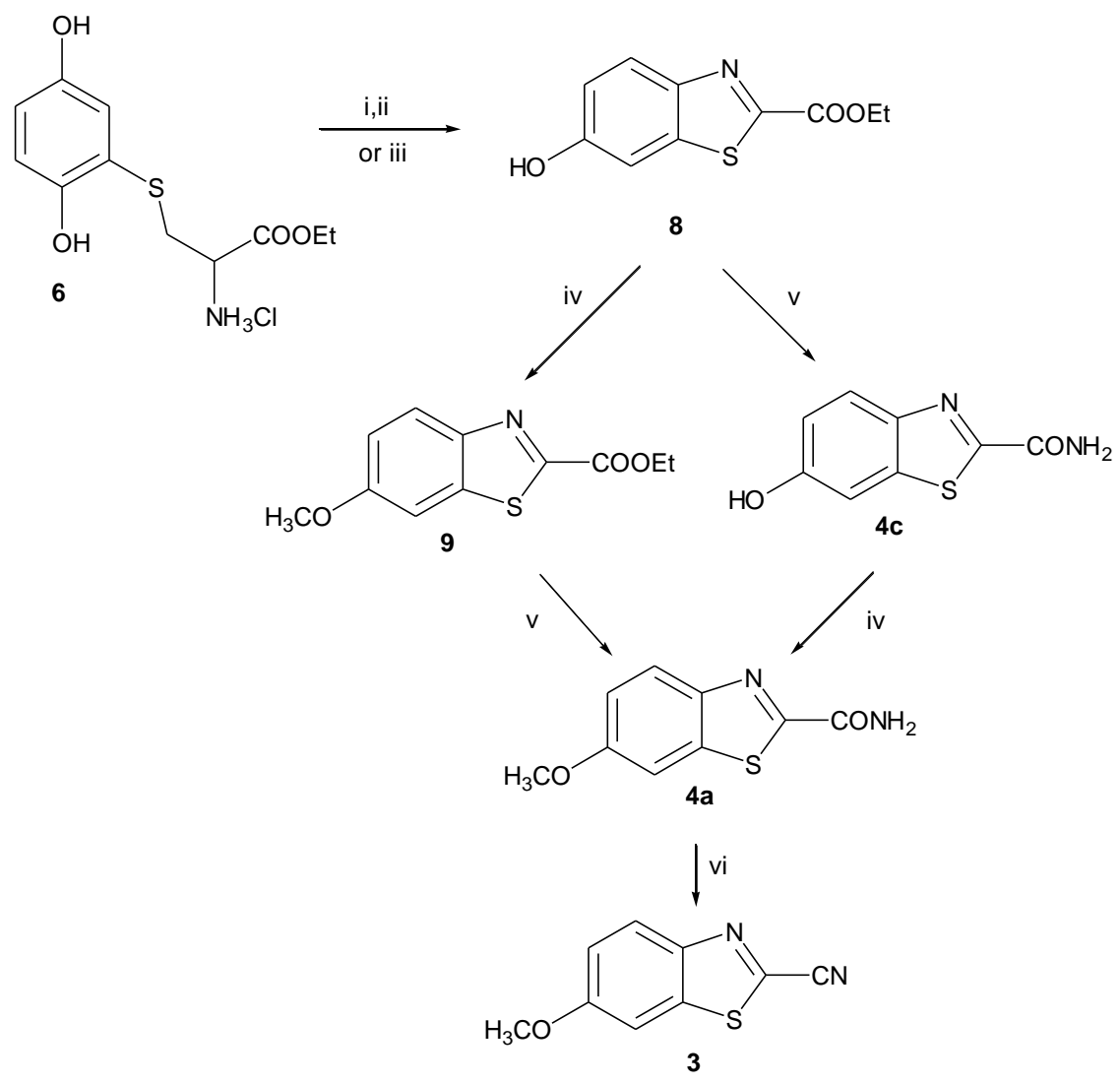

Scheme 3. Preparation of 2-substituted 6-hydroxy and 6-methoxybenzothiazoles from ethyl 6hydroxybenzothiazole-2-carboxylate 8. Reagents and conditions: (i) aq. $\mathrm{K}_{3} \mathrm{Fe}(\mathrm{CN})_{6}, \mathrm{NaOH}$, 
iPrOH, room temperature, $1.5 \mathrm{~h}$; (ii) silica gel chromatography, 68\%; (iii) $\mathrm{CuBr}_{2}$ in $\mathrm{iPrOH} / \mathrm{H}_{2} \mathrm{O}$, room temperature, $2 \mathrm{~h}, 65 \%$; (iv) $\mathrm{MeI} / \mathrm{K}_{2} \mathrm{CO}_{3} / \mathrm{DMF}$, reflux, $1 \mathrm{~h}, 92 \%$; (v) $\mathrm{NH}_{4} \mathrm{OH} / \mathrm{EtOH}$, reflux, 5 h, 98\%; (vi) $\mathrm{POCl}_{3}, \mathrm{Py} / \mathrm{CH}_{2} \mathrm{Cl}_{2}$, room temperature, 12 h, $72 \%$.

\section{Conclusions}

We have reported a new approach to the synthesis of a few 2-substituted 6-hydroxy and 6methoxybenzothiazoles starting from 1,4-benzoquinone 5. Ethyl (R)-2-amino-3-(2,5dihydroxyphenylsulfanyl)propanoate hydrochloride $\mathbf{6}$ has been prepared by an improved procedure and the oxidation of this intermediate to the benzothiazole ester $\mathbf{8}$ has been ameliorated. According to the experimental protocol outlined in our work, the key intermediate for the synthesis of D-luciferin, 2-cyano-6-methoxybenzothiazole 3, can be prepared in $42 \%$ yield. This is worth of note, since yields are higher than those obtained following the classical approach $(9.9 \%)^{10}$ and comparable with the most convenient synthesis based on a Sandmeyer approach, using poisonous cyanides $(48,6 \%) .{ }^{13,14}$ Finally, our synthetic approach opens the possibility of preparing 2,6-disubstituted benzothiazoles suitable for ${ }^{18} \mathrm{~F}$ labeling such as compounds $\mathbf{2 a}$ starting from properly substituted 1,4-benzoquinones. Alternatively, from the ester $\mathbf{8}$ also new ${ }^{18} \mathrm{~F}$-labeled amides $\mathbf{2 d}$ may become available.

\section{Experimental Section}

General. Melting points were recorded on a Stuart Scientific SMP3 instrument and are uncorrected. ${ }^{1} \mathrm{H}$ - and ${ }^{13} \mathrm{C}-\mathrm{NMR}$ spectra were recorded at $303 \mathrm{~K}$ on a Bruker AM-500 spectrometer equipped with an Aspect 3000 computer, a process control and an array processor. The ${ }^{1} \mathrm{H}$ - and ${ }^{13} \mathrm{C}$ chemical shifts are reported in parts per million, using as reference the signal for residual solvent. The progress of all reactions and column chromatography were monitored by TLC using Silica Gel $60 \mathrm{~F}_{254}$ precoated plates with a fluorescent indicator (Merck). Purification of products by chromatography was performed using silica gel 60 (230-400 mesh, Merck). All reagents were obtained from commercial sources and used without further purification.

Ethyl (R)-2-amino-3-(2,5-dihydroxyphenylsulfanyl)propanoate hydrochloride 6. A solution of 1,4-benzoquinone $5(0.997 \mathrm{~g}, 9.24 \mathrm{mmol})$ in $\mathrm{MeOH}(20 \mathrm{~mL})$ is added dropwise to a solution of L-cysteine ethyl ester hydrochloride (1.715 g, $9.24 \mathrm{mmol})$ in $\mathrm{MeOH}(10 \mathrm{~mL})$ under nitrogen and stirring at room temperature $(1.5 \mathrm{~h})$. The reaction is monitored by TLC (petroleum ether/ethyl acetate, 6/4) and upon completion the solvent is evaporated. Ethyl acetate is added $(10 \mathrm{~mL})$ to wash the crude product and then is removed by decantation. The operation is repeated with diethyl ether and dichloromethane and the ester $\mathbf{6}$ is obtained as a solid. The ester $\mathbf{6}$ is a hygroscopic compound that can be obtained and stored at room temperature if ambient moisture 
is properly excluded. A freshly prepared sample decomposes at $130{ }^{\circ} \mathrm{C} ;{ }^{1} \mathrm{H}-\mathrm{NMR}$ (in $\mathrm{CD}_{3} \mathrm{OD}$ ) $\delta$ $1.12(\mathrm{t}, 3 \mathrm{H}), 3.32(\mathrm{dd}, 1 \mathrm{H}, J=4.9$ and $15.6 \mathrm{~Hz}), 3.57(\mathrm{dq}, 1 \mathrm{H}, J=7.1$ and $10.5 \mathrm{~Hz}), 3.82(\mathrm{dd}, 1 \mathrm{H}$, $J=4.4$ and $15.3 \mathrm{~Hz}), 3.97(\mathrm{dq}, 1 \mathrm{H}, \mathrm{J}=7.1$ and $10.5 \mathrm{~Hz}), 4.15(\mathrm{~m}, 1 \mathrm{H}), 6.65(\mathrm{dd}, 1 \mathrm{H}, J=2.9$ and $8.8 \mathrm{~Hz}), 6.70(\mathrm{~d}, 1 \mathrm{H}, J=8.8 \mathrm{~Hz}), 6.85\left(\mathrm{~d}, 1 \mathrm{H}, J=2.9 \mathrm{~Hz}\right.$ ); ${ }^{13} \mathrm{C}-\mathrm{NMR}$ (in $\mathrm{CD}_{3} \mathrm{OD}$ ) $\delta 12.2,33.5$, $51.5,61.9,115.6,116.1,116.8,120.7,149.9,150.1,166.9$.

Ethyl 6-hydroxybenzothiazole-2-carboxylate 8. a. $\mathrm{K} 3 \mathrm{Fe}(\mathrm{CN})_{6}$ oxidation. To a solution of the ester $6(1.755 \mathrm{~g}, 5.98 \mathrm{mmol})$ in isopropanol $(45 \mathrm{~mL})$ an aqueous solution of $1 \mathrm{M} \mathrm{K}_{3} \mathrm{Fe}(\mathrm{CN})_{6}(36$ $\mathrm{mL})$ and $4 \mathrm{M} \mathrm{NaOH}(2.5 \mathrm{~mL})$ is added. The mixture is stirred at room temperature $(1.5 \mathrm{~h})$ and monitored by TLC (dichloromethane/methanol, 95/5). At the end of the reaction, water is added and the product extracted with ethyl acetate, that is then washed with brine. After removal of the solvent at reduced pressure, the product is purified by column cromatography (petroleum ether/ethyl acetate, 7/3). Yield of compound 8: $0.910 \mathrm{~g}(68 \%)$.

b. Reaction with $\mathrm{Cu}(\mathrm{II})$ salts. To a solution of the ester $6(0.425 \mathrm{~g}, 1.45 \mathrm{mmol})$ in isopropanol $(15 \mathrm{~mL})$ an aqueous solution of $\mathrm{CuBr}_{2}(0.965 \mathrm{~g}, 4.335 \mathrm{mmol})$ in water $(15 \mathrm{~mL})$ is added. The mixture is stirred at room temperature $(2 \mathrm{~h})$ and monitored by TLC (dichloromethane/methanol, 95/5). At the end of the reaction, water is added and the product extracted with ethyl acetate, that is then washed with brine. After removal of the solvent at reduced pressure, the ester $\mathbf{8}$ is purified by column chromatography (petroleum ether/ethyl acetate, 7/3). Yield: $0.210 \mathrm{~g}(65 \%)$; mp 178$180{ }^{\circ} \mathrm{C}$ (lit. 172-173 ${ }^{\circ} \mathrm{C}$ ) ${ }^{21} .{ }^{1} \mathrm{H}-\mathrm{NMR}$ (in DMSO) $\delta 1.35$ (t, $3 \mathrm{H}, J=7.2 \mathrm{~Hz}$ ), 4.42 (q, $2 \mathrm{H}, J=7.2$ $\mathrm{Hz}), 7.10(\mathrm{dd}, 1 \mathrm{H}, J=2.5$ and $9.0 \mathrm{~Hz}), 7.47(\mathrm{~d}, 1 \mathrm{H}, \mathrm{J}=2.5 \mathrm{~Hz}), 8.00(\mathrm{dd}, 1 \mathrm{H}, \mathrm{J}=2.5$ and $9.0 \mathrm{~Hz})$, 10.3 (s, 1H); ${ }^{13} \mathrm{C}-\mathrm{NMR}$ (in $\mathrm{CD}_{3} \mathrm{OD}$ ) $\delta$ 15.0, 62.6, 106.0, 118.0, 126.0, 139.1, 147.9, 155.8, 158.4, 161.0. Anal. Calcd. for $\mathrm{C}_{10} \mathrm{H}_{9} \mathrm{NO}_{3} \mathrm{~S}$ : C, 53.80; H, 4.06; N, 6.27; Found: C, 53.88; H, 4.12; N, 6.18 .

Ethyl 6-methoxybenzothiazole-2-carboxylate 9. To a solution of the ester $8(1.20 \mathrm{~g}, 5.38$ $\mathrm{mmol})$ in DMF $(15 \mathrm{~mL})$, potassium carbonate $(1.115 \mathrm{~g}, 8.07 \mathrm{mmol})$ is added and the suspension stirred at room temperature $(30 \mathrm{~min})$. Methyl iodide $(0.504 \mathrm{~mL}, 8.07 \mathrm{mmol})$ is added and the suspension is refluxed for $1 \mathrm{~h}$, monitoring the reaction by TLC (dichloromethane/methanol, 95/5). At the end, brine is added and the product is extracted wit ethyl acetate. The organic solvent is removed to leave the pure ester $9(1.172 \mathrm{~g}, 92 \%)$ as a yellow solid; mp 67-69 ${ }^{\circ} \mathrm{C} .{ }^{1} \mathrm{H}-\mathrm{NMR}$ (in $\left.\mathrm{CDCl}_{3}\right) \delta 1.48(\mathrm{t}, 3 \mathrm{H}, \mathrm{J}=8.7 \mathrm{~Hz}$ ), $3.88(\mathrm{~s}, 3 \mathrm{H}), 4.53(\mathrm{q}, 2 \mathrm{H}, J=8.7 \mathrm{~Hz}), 7.15$ (dd, 1H, J=2.5 and $9.0 \mathrm{~Hz}), 7.36(\mathrm{~d}, 1 \mathrm{H}, J=2.5 \mathrm{~Hz}), 7.98(\mathrm{~d}, 1 \mathrm{H}, 5-\mathrm{H}, J=8.7 \mathrm{~Hz}), 8.08(\mathrm{dd}, 1 \mathrm{H}, J=2.5$ and $9.0 \mathrm{~Hz})$; ${ }^{13} \mathrm{C}-\mathrm{NMR}$ (in $\mathrm{CDCl}_{3}$ ) $\delta 15.00,55.55,62.60,103.95,118.00,126.50,139.05,148.00,156.10$, 159.95, 161.00. Anal. Calcd. for $\mathrm{C}_{11} \mathrm{H}_{11} \mathrm{NO}_{3} \mathrm{~S}$ : C, 55.70; H, 4.64; N,5.90; Found: C, 55.79; H, $4.72 ; \mathrm{N}, 5.85$.

6-Methoxybenzothiazole-2-carboxyamide 4a. A solution of the ester 9 (1.100 g, $4.641 \mathrm{mmol})$ in ethanol $(50 \mathrm{~mL})$ is treated with concentrated aqueous ammonia $(20 \mathrm{~mL})$ and the mixture refluxed $(5 \mathrm{~h}$ ). The reaction is monitored by TLC (dichloromethane/methanol, 95/5) and at the end the reaction mixture is evaporated under vacuum. The residue is treated with 
dichloromethane/methanol (8/2), filtered on Florisil (20 g) and the amide 4a is crystallized from methanol/chloroform (1:10) as a brown solid (0.965 g, 98\%); mp 248-250 ${ }^{\circ} \mathrm{C} \mathrm{dec}$ (lit. 257-258 $\left.{ }^{\circ} \mathrm{C}\right)^{28} ;{ }^{1} \mathrm{H}-\mathrm{NMR} \delta 3.85(\mathrm{~s}, 3 \mathrm{H}), 7.20(\mathrm{~d}, 1 \mathrm{H}, J=8.7 \mathrm{~Hz}), 7.75(\mathrm{~s}, 1 \mathrm{H}), 7.98(\mathrm{~d}, 1 \mathrm{H}, J=8.7 \mathrm{~Hz}), 7.95$ $\left[(\mathrm{bs}, 1 \mathrm{H})\right.$ and $\left.8.35(\mathrm{bs}, 1 \mathrm{H}), \mathrm{CONH}_{2}\right] ;{ }^{13} \mathrm{C}-\mathrm{NMR} \delta 55.60,104.00,117.90,125.95,138.65$, 147.80, 156.70, 160.95, 166.10. Anal. Calcd. for $\mathrm{C}_{9} \mathrm{H}_{8} \mathrm{~N}_{2} \mathrm{O}_{2} \mathrm{~S}: \mathrm{C}, 51.92 ; \mathrm{H}, 3.85 ; \mathrm{N}, 13.46$. Found: C, 52.09; H, 3.93; N, 13.40.

2-Cyano-6-methoxybenzothiazole 3. To a solution containing the amide 4a $(0.95 \mathrm{~g}, 4.567$ $\mathrm{mmol})$ and imidazole $(0.311 \mathrm{~g}, 4.567 \mathrm{mmol})$ in anhydrous pyridine $(25 \mathrm{~mL})$, cooled at $-10^{\circ} \mathrm{C}$ under nitrogen, a solution of $\mathrm{POCl}_{3}(0.835 \mathrm{~mL}, 9.134 \mathrm{mmol})$ in dichloromethane $(5 \mathrm{~mL})$ is added. The temperature is slowly raised and stirring is continued for $12 \mathrm{~h}$, monitoring the reaction by TLC (petroleum ether/ethyl acetate, 8/2). At the end, dichloromethane is added, then water, and the organic phase is separated, the solvent removed and the crude purified by column chromatography (petroleum ether/ethyl acetate, 9/1). The nitrile $\mathbf{3}$ is obtained as a yellow solid (0.625 g, 72\%); mp 129-130 ${ }^{\circ} \mathrm{C}$ (lit. 129-130 ${ }^{\circ} \mathrm{C}$ ) ${ }^{11} .{ }^{1} \mathrm{H}-\mathrm{NMR}\left(\right.$ in $\left.\mathrm{CDCl}_{3}\right) \delta 3.93$ (s, 3H), 7.24 (dd, $1 \mathrm{H}, J=2.5$ and $9.0 \mathrm{~Hz}), 7.36(\mathrm{~d}, 1 \mathrm{H}, J=2.5 \mathrm{~Hz}), 8.08\left(\mathrm{dd}, 1 \mathrm{H}, J=2.5\right.$ and $9.0 \mathrm{~Hz}$ ); ${ }^{13} \mathrm{C}-\mathrm{NMR}$ (in $\left.\mathrm{CDCl}_{3}\right) \delta$ 56.7, 103.7, 113.9, 119.2, 126.5, 134.0, 138.1, 147.6, 161.2. Anal. Calcd. for $\mathrm{C}_{9} \mathrm{H}_{6} \mathrm{~N}_{2} \mathrm{OS}: \mathrm{C}, 56.82 ; \mathrm{H}, 3.18$; N, 14.73; Found: C, 56.86; H, 3.22; N, 14.68.

\section{Acknowledgements}

This work has been financially supported by the European Project EMIL (European Molecular Imaging Laboratories, LSHC-Ct-2004-503569) entitled "Molecular Imaging for Early Detection of Tumors and Monitoring of Treatment".

\section{References and Notes}

1. White, E. H.; Rapaport, E.; Seliger, H. H.; Hopkins, T. A. Bioorg. Chem. 1971, 1, 92.

2. Roda, A.; Pasini, P.; Mirasoli, M.; Michelini, E.; Guardigli, M. Trends Biotechnol. 2004, 22, 295.

3. (a) Söling, A.; Rainov, N.G. Expert. Opin. Biol. Ther. 2003, 3, 1163. (b) Lüker, G.D.; Lüker, K. E. J. Nucl. Med. 2008, 49, 1.

4. (a) Ametamey, S.M.; Honer, M.; Schubiger, P.A. Chem. Rev. 2008, 108, 1501. (b) Miller, P. W.; Long, N, J.; Vilar, R.; Gee, A, D. Angew. Chem. Int. Ed. 2008, 47, 8998.

5. Ciana, P.; Raviscioni, M.; Mussi, P.; Vegeto, E.; Que, I.; Parker, M. G.; Lowik, C.; Maggi, A. Nat. Med. 2003, 9, 82 .

6. Denburg, J. L.; Lee, R. T.; McElroy, W. D. Archiv. Biochem. Biophys. 1969, 134, 381.

7. Auld, D. S.; Southall, N. T.; Jadhav, A.; Johnson, R. L.; Diller, D. J.; Simeonov, A.; Austin, C. P.; Inglese, J. J. Med. Chem. 2008, 51, 2372. 
8. Meroni, G.; Ciana, P.; Meda, C.; Maggi, A.; Santaniello, E. Arkivoc 2009, (xi), 22.

9. White, E. H.; McCapra, F.; Field, G. F.; McElroy, W. D. J. Am. Chem. Soc. 1961, 83, 2402.

10. White, E. H.; McCapra, F.; Field, G. F.; J. Am. Chem. Soc. 1963, 85, 337.

11. Seto, S.; Ogura, K.; Nishiyama, Y. Bull. Chem. Soc. Jpn. 1963, 36, 332.

12. Bowie, L. J. Methods. Enzymol. 1978, 57, 15.

13. Suzuki, N.; Nomoto, T., Kanamori, N.; Yoda, B.; Saeki, A. Biosci. Biotech. Bioch. 1993, 57, 1561.

14. Toya, Y.; Takagi, M.; Nakata, H.; Suzuki, N.; Isobe, M.; Goto, T. Bull. Chem. Soc. Jpn. 1992, 65, 392.

15. Bénéteau, V.; Besson, T.; Rees, C. W. Synthetic Commun. 1997, 27, 2275.

16. Meroni, G.; Rajabi, M.; Santaniello, E. Arkivoc 2009, (i), 265.

17. Kuhn, R.; Beinert, H. Chem. Ber. 1944, 77, 606.

18. Prota, G.; Ponsiglione, E. Tetrahedron. Lett. 1972, 13, 1327.

19. Crescenzi, O.; Prota, G.; Schultz, T.; Wolfram, L. J. Tetrahedron 1988, 44, 6447.

20. Crescenzi, O.; Prota, G.; Schultz, T.; Wolfram, L. J. Gazz. Chim. It. 1990, 120, 21.

21. Löwik, D. W. P. M.; Tisi, L. C.; Murray, J. A. H.; Lowe, C. R. Synthesis 2001, 1780.

22. When the reaction of 1,4-benzoquinone and L-cysteine ethyl ester hydrochloride was carried out in aqueous methanol the ester $\mathbf{6}$ was recovered as a hygroscopic compound (see reference 20). According to our procedure, a solid can be obtained and stored at room temperature if ambient moisture is properly excluded.

23. In reference 21 , it was reported that when the oxidation of the ester $\mathbf{6}$ was carried out in isopropanol with $\mathrm{K}_{3} \mathrm{Fe}(\mathrm{CN})_{6}$ and $\mathrm{NaOH}$, the corresponding benzothiazine could not isolated by silica gel chromatography. In fact, in these conditions the compound was directly transformed into the benzothiazole ester $\mathbf{8}$.

24. The reaction of the 1,4-benzoquinone portion of rifamycin $S$ with cysteine methyl ester and following oxidation bring to the formation of a benzothiazole system; see: (a) Cricchio, R. Tetrahedron. 1980, 36, 1415. (b) Cricchio, R. Tetrahedron 1980, 36, 2009. Accordingly, we have used a few oxidants reported in these works (DDQ, $\mathrm{MnO}_{2}, 1,4$-benzoquinone) and other reagents such as Dess-Martin, pyridinium chlorochromate, or sodium chlorite. However, in general, unsatisfactory results were obtained.

25. For other examples of use of cupric salts for the synthesis of benzothiazoles, see: (a) Moghaddam, F. M.; Ismaili, H.; Bardajee, G. R. Heteroatom Chem. 2006, 17, 136; (b) Meshram, H. M.; Kumar, D. A.; Prasad, R. V. Synthetic Commun. 2009, 39, 2317.

26. Liso, G.; Trapani, G.; Latrofa, A. J. Heterocyclic Chem. 1987, 24, 1683.

27. Van der Veken, P.; Senten, K.; Kertèsz, I.; De Meester, I.; Lambeir, A. M.; Maes, M. B.; Scharpé, S.; Haemers, A.; Augustyns, K. J. Med. Chem. 2005, 48, 1768.

28. Yarovenko, V. N.; Stoyanovich, F. M.; Zolotarskaya, O. Y.; Chernoburova, E. I.; Zavarzin, I. V.; Krayushkin, M. M. Russ. Chem. Bull. Int. Ed. 2002, 51, 144. 